\title{
Feeding and other management practices of Pulikulam cattle rearers in its native tract
}

\author{
G Srinivasan $^{1}$, Valli Chinnamani ${ }^{2}$, M Chellapandian $^{3}$, V Leela $^{4}$ and T Sathiamoorthy ${ }^{1}$
}

Received: 06 June 2021 / Accepted: 25 June 2021 / Published online: 07 September 2021

(C) Indian Dairy Association (India) 2021

\begin{abstract}
Pulikulam cattle are native cattle breed of southern Tamil Nadu reared by the nomadic herd rearers and bull rearers. A field study was conducted to collect information on existing management practices followed by the Pulikulam cattle rearers at Pulikulam cattle breeding tract during November, 2020. A total of 60 nomadic rearers and 60 Pulikulam bull rearers were randomly selected from the breeding tract. Nomadic rearers practising grazing only, $70 \%$ of them migrate for grazing throughout the breeding tract. Grazing at hilly area was practised by 16.67 percent respondents and 13.33 percent respondents grazed at common pasture land. Sale of manure and male calves were the main source of income for the nomadic cattle rearers. Milking was practiced only in the morning time by the nomadic rearers in the Sivaganga district. Concentrate feed or mineral mixture feeding was not practised by the nomadic Pulikulam cattle rearers. It is concluded that no scientific management practices especially feeding management is in practice. Adoption of balanced feeding and supplementation with mineral mixture could improve the performance of this breed of cattle.
\end{abstract}

Keywords: Bull baiting game, Feeding Management, Native Cattle breed, Nomadic herd and Pulikulam Cattle

\footnotetext{
${ }^{1}$ Pulikulam Cattle Research Station, Manamadurai- 630606 Tamil Nadu, India

${ }^{2}$ Professor and Head, Institute of Animal Nutrition, Tamil Nadu Veterinary and Animal Sciences University, Kattupakkam- 603202

${ }^{3}$ Department of Animal Nutrition, Veterinary College and Research Institute, Tirunelveli-627 358 ${ }^{4}$ Department of Veterinary Physiology, Madras Veterinary College,
Chennai- 600007

G Srinivasan $(\bowtie)$

Pulikulam Cattle Research Station

Manamadurai- 630606 Tamil Nadu, India

Email: govisri4@gmail.com
}

Management practices play a major role in exploiting full potential of dairy animals. Feeding management is one of the important factors in dairy farming which constitutes 70 per cent of production cost. However, traditional animal keepers follow own feeding, breeding and housing practices for their herd (Sheikh et al. 2011). Documenting the management practices are important to understand the strength and weakness of animal rearing system and it will be helpful to identify appropriate scientific interventions to improve the management practices thereby improve the livelihood of the livestock farmers. Pulikulam cattle are native breed of southern Tamil Nadu reared in Sivaganga, Madurai and Virudhunagar districts. The breeding tract of Pulikulam cattle lies between $9^{\circ} 30^{\prime}$ and $10^{\circ} 30^{\prime} \mathrm{N}$ latitude and between $77^{\circ} 47^{\prime}$ and $78^{\circ} 49^{\prime} \mathrm{E}$ longitude. The climate of the region is semi-arid tropical and the mean temperature during summer is $42^{\circ} \mathrm{C}$ to $43^{\circ} \mathrm{C}$ and relative humidity is 40 to $45 \%$. The predominant soil of Sivaganga district is black red sandy soil and it falls in the southern zone of agro-climatic zone of Tamil Nadu. (Sivaganga district groundwater brochure, 2008). Pulikulam cattle are comparatively smaller than Kankeyam cattle, other native cattle of Tamil Nadu but are very active and capable of much endurance. The average weight of female cow is $200 \mathrm{kgs}$ and bull is $350 \mathrm{kgs}$. The Pulikulam cattle have moderately long face, well developed hump which is short in female and large in male, horns are long, curved inside with pointed edges and the ears are moderately long (Srinivasan and Sathiamoorthy 2020). The Pulikulam bulls are very vigorous mainly maintained for jallikattu or bull baiting game.

Pulikulam cattle are reared by two types of rearers. One type of rearers keep the Pulikulam cattle as a nomadic herd and other group of rearers rear only bulls for bull baiting game. The Pulikulam cattle are mainly reared in herds of 50 to 500 animals mostly kept in open area in the outskirts of villages. The main source of income for the Pulikulam cattle rearers are through the sale of manure, manure sold through a system of penning and also through the sale of male calves. The prominent male calves from the nomadic herds are being purchased by the bull rearers and trained for jallikattu or bull baiting game. The management practices of Pulikulam cattle show a lot of variations among the farmers. Hence, this study was conducted to document the management practices followed by the Pulikulam cattle rearers in its breeding tract. 
The present study was conducted in Pulikulam cattle breeding tract viz., Sivaganga Madurai and Virudhunagar districts of Tamil Nadu, India during November, 2020. A field study was carried out to collect information on the management practices followed by the Pulikulam cattle rearers, both nomadic rearers and bull rearers. A total of 60 nomadic rearers and 60 Pulikulam bull rearers were selected randomly from three districts viz., Sivaganga, Madurai and Virudhunagar and data were collected using personal interview technique through structural schedule. The data was tabulated and interference was drawn.
Feeding management practices adopted by the nomadic Pulikulam cattle rearers and Pulikulam bull rearers are presented in Table1.

Majority (83.33\%) of the Nomadic Pulikulam cattle rearers migrate thoughout the breeding tract for the purpose of grazing their animals and follow fixed route for grazing for particular months. Mostly they migrate after harvesting of paddy crop. They keep the animals in their own village or any particular village for a period of five to six months, remaining six months they migrate for grazing, as well as to earn revenue through manure by adopting penning. Penning is a practice in which the Pulikulam

Table 1 Feeding Management followed by Pulikulam cattle rearers

\begin{tabular}{|c|c|c|c|c|c|}
\hline \multirow[t]{2}{*}{ S. No } & \multirow[t]{2}{*}{ Management Practice } & \multicolumn{2}{|c|}{ Nomadic rearers $(\mathrm{n}=60)$} & \multicolumn{2}{|c|}{ Bull rearers $(n=60)$} \\
\hline & & Frequency & Per cent & Frequency & Per cent \\
\hline \multirow[t]{3}{*}{1} & Type of rearing & & & & \\
\hline & Nomadic/ Migratory & 50 & 83.33 & 0 & 0 \\
\hline & Stationary & 10 & 16.67 & 60 & 100 \\
\hline \multirow[t]{4}{*}{2} & Feeding pattern & & & & \\
\hline & Grazing only & 60 & 100 & 42 & 70.00 \\
\hline & Stall feeding & 0 & 0 & 8 & 13.33 \\
\hline & Grazing with stall feeding & 0 & 0 & 10 & 16.67 \\
\hline \multirow[t]{6}{*}{3} & Grazing site & & & & \\
\hline & Common pasture land & 08 & 13.33 & 36 & 60.00 \\
\hline & Harvested field & 0 & 0 & 12 & 20.00 \\
\hline & Fallow land & - & 0 & 12 & 20.00 \\
\hline & Hilly area & 10 & 16.67 & 0 & 0 \\
\hline & Migrate for grazing & 42 & 70 & 0 & 0 \\
\hline \multirow[t]{3}{*}{4} & Feeding of cultivated green fodder & & & & \\
\hline & Yes & 0 & 0 & 8 & 13.33 \\
\hline & No & 60 & 100 & 52 & 86.67 \\
\hline \multirow[t]{3}{*}{5} & Type of dry fodderfed & & & & \\
\hline & Paddy straw & 0 & 0 & 48 & 80.00 \\
\hline & Others dry fodder & 0 & 0 & 12 & 20.00 \\
\hline \multirow[t]{3}{*}{6} & Concentrate feeding & & & & \\
\hline & Yes & 0 & 0 & 58 & 96.67 \\
\hline & No & 60 & 100 & 2 & 03.33 \\
\hline \multirow[t]{3}{*}{7} & Type of concentrate with grazing & & & & \\
\hline & Rice bran and oil cake & 0 & 0 & 44 & 73.33 \\
\hline & Rice bran, grain and gram dust & 0 & 0 & 16 & 26.67 \\
\hline \multirow[t]{5}{*}{8} & Feeding of tree fodder & & & & \\
\hline & Yes & 4 & 6.67 & 22 & 36.67 \\
\hline & No & 56 & 93.33 & 38 & 63.33 \\
\hline & $\begin{array}{l}\text { Leucaenaleucocephala/Sesbania } \\
\text { grandiflora }\end{array}$ & 54 & 90 & 54 & 90.00 \\
\hline & Other tree fodder & 06 & 10 & 06 & 10.00 \\
\hline \multirow[t]{3}{*}{9} & Feeding of mineral mixture & & & & \\
\hline & Yes & 0 & 0 & 0 & 0 \\
\hline & No & 60 & 100 & 60 & 100 \\
\hline \multirow[t]{3}{*}{10} & Special feeding after calving & & & & \\
\hline & Yes & 02 & 3.33 & 0 & 0 \\
\hline & No & 58 & 96.67 & 0 & 0 \\
\hline
\end{tabular}


cattle are kept in the agricultural land of farmers for one night, the manure and urine that the animals excrete nourish the field and thereby the nutrient status of the soil of the agricultural land is improved.

Apart from that only 16.67 per cent of Pulikulam cattle rearers keep their animals in their village. They do not migrate to different places for grazing. These rearers are present only in Sivaganga taluk of Sivaganga district. In case of Pulikulam bull rearers, all the respondents $(100 \%)$ keep the bulls only in their villages.

It could be inferred from Table 1 that all the nomadic rearers follow grazing practise only. However, 70.00, 13.33 and 16.67 percent of Pulikulam bull rearers followed grazing, stall feeding and grazing with stall feeding practices respectively. The data on grazing site for nomadic rearers revealed that $70 \%$ of the respondents migrate for grazing throughout the breeding tract, 16.67 percent respondents grazed at hilly area and 13.33 percent respondents grazed their animals at common pasture land.

In Pulikulam bull rearers 60 per cent grazed at common pasture land followed by 20 per cent at harvested field and 20 per cent grazed at fallow land. Patel et al. (2016) reported that majority of professional Kankrej cattle breeders in Banaskantha district were landless and marginal farmers. They mainly depend on grazing their animals on common property resources (Gochars). All the respondents in the Nomadic rearers group did not feed cultivated green fodder. Because, majority of them rearing Pulikulam cattle as a nomadic herd. In Pulikulam bull rearing group majority $(86.67$ $\%)$ of respondents did not feed cultivated green fodder, only 13.33 per cent respondents fed green fodder to their bulls and that was also only during the monsoon season. Similar finding was observed by Garg et al. (2005) and Sinha et al. (2009).

The nomadic rearers did not feed any dry fodder to their animals. But 80 per cent of Pulikulam bull rearers fed paddy straw as dry fodder and 20 per cent of bull rearers fed other locally available dry fodders. Results of this finding are in line with Sabapara et al. (2010) that 98 per cent of farmers in the tribal areas of south Gujarat fed only paddy straw and 2 per cent farmers fed sorghum straw. Similar findings were observed by Tomar and Thakur (2002) and Deoras et al. (2004). Rathore et al. (2010) reported that pearl millet was the main dry fodder fed by the cattle keepers of Churu district of Rajasthan. Godara et al. (2018) reported that wheat straw was the main dry fodder with pearl millet fed by the buffalo rearing farmers of western Haryana.

No respondents in the nomadic rearers group fed concentrate feed to their animals. In Pulikulam bull rearers 96.67 percent respondents fed concentrate feed to their bulls only three months prior to jallikattu or bull baiting game season, remaining period they did not feed concentrate feed. Results of this finding is contrary to the finding of Kumar et al. (2017) that majority of the
Table 2 Milking management and other management followed by Pulikulam Cattle rearers $(n=60)$

\begin{tabular}{|c|c|c|}
\hline S. No & Management practice & Per cent \\
\hline \multirow[t]{3}{*}{$\overline{1}$} & Milking method & \\
\hline & Machine & 0 \\
\hline & Hand milking & 100 \\
\hline \multirow[t]{3}{*}{2} & Frequency of milking & \\
\hline & Once per day & 100 \\
\hline & Twice per day & \\
\hline \multirow[t]{4}{*}{3} & Gender of milking person & \\
\hline & Male & 10 \\
\hline & Female & \\
\hline & Both & 90 \\
\hline \multirow[t]{3}{*}{4} & Practice of let down of milk & \\
\hline & Allow calf to suck & 100 \\
\hline & Feed concentrate and udder massage & \\
\hline \multirow[t]{3}{*}{5} & Washing of hand before milking & \\
\hline & Yes & 100 \\
\hline & No & 0 \\
\hline \multirow[t]{4}{*}{6} & Milk production & \\
\hline & Less than one liters per day & 30 \\
\hline & $1-2$ lites per day & 70 \\
\hline & More than 2 liters per day & 0 \\
\hline \multirow[t]{3}{*}{7} & Practice of weaning & \\
\hline & Yes & 0 \\
\hline & No & 100 \\
\hline \multirow[t]{3}{*}{8} & Sale of Manure & \\
\hline & Yes & 100 \\
\hline & No & 0 \\
\hline \multirow[t]{3}{*}{9} & Price of dry manure & \\
\hline & Rs. 1/ kg & 20 \\
\hline & Rs. $1-2 / \mathrm{Kg}$ & 80 \\
\hline \multirow[t]{3}{*}{10} & Sale of calves & \\
\hline & Male calves & 100 \\
\hline & Female calves & 0 \\
\hline
\end{tabular}

indigenous cattle farmers of Thar district of Rajasthan fed concentrate feed to their cattle.

All the bull rearers fed only homemade concentrate mixture. 73.33 per cent respondents mix only rice bran and oilcake and 26.67 per cent respondents mix rice bran, grain and gram dust in concentrate feed mix. Result of this finding is contrary to the findings of Kumar et al. (2017) that 38.4 percent of indigenous cattle farmers fed only purchased concentrate mix and 61.6 per cent respondents fed both homemade and purchased concentrate feed. Sabapara et al. (2010) reported that 7 per cent of farmers fed only home produced concentrate mix and 4 per cent respondents provided compounded cattle feed. Similar finding was observed by Garg et al. (2005).

Majority (93.33\%) of nomadic rearers did not feed tree fodder only 6.67 per cent respondents fed tree fodder. In Pulikulam bull rearers group only 36.67 percent respondents fed tree fodders to 
their bulls and 63.33 per cent did not feed any tree fodder to their bulls. Sesbania grandiflora or Leuceana leucocephala is the main tree fodder fed by majority $(90 \%)$ of respondents remaining 10 per cent respondents fed other tree fodders. Cent per cent in the nomadic rearers group and Pulikulam bull rearers group did not give mineral mixture to the animals. Results of this finding is in accordance with results of Godara et al. (2018) who reported that 61 per cent of buffalo farmers in the western Haryana did not feed any mineral mixture to the animals. Findings of Manohar et al. (2014) and Dixit et al. (2010) were also at par with this result.

Majority (96.67\%) of the respondents in the nomadic rearers group did not provide any special feed to cows after calving only 3.33 percent respondents provide energy rich feeds to cows after calving. Contrary to this finding of this study Sabapara et al. (2010) reported that majority of the respondents (96\%) maintaining dairy animals in the tribal area of south Gujarat followed to feed special feeding after calving. They fed energy rich feed mixed with echbolic ingredients. The energy rich feed will meet out the immediate energy requirement due to colostrum or milk production. Similar finding was reported by Divekar and Saiyed (2008).

Milking management and other management practices followed by the Pulikulam cattle rearers are presented in Table 2.Milking of Pulikulam cattle is practised only in Sivaganaga district. All the respondents in the district practised hand milking only. Result obtained in the present study is similar with finding of Kumar et al. (2017) who reported that all the Indigenous cattle rearers in Thar district of Rajasthan adopted hand milking only. All the respondents in the present study milked only one time per day only in the morning. Seventy per cent of respondents reported milk yield per animal as1- 2 liters per day and 30 percent of respondents reported less than one liter of milk per day per animal. Evening milking was not practised by any of the respondents. All the respondents (100\%) did not practise weaning of calves so calves were allowed to suck throughout the day. In respect to the gender of the milking person, 10 per cent were men only and 90 per cent were either men or women. Findings of Sheikh and Parmar (2015) and Kumar et al. (2017) were in line with the present study. All the respondents allowed calf to suck the udder to stimulate let down of milk. The results of this study are similar as observed by Garg et al. (2005) and Kumar et al. (2006). Regarding Clean milk production practice all the respondents $(100 \%)$ washed their hands before milking. This finding is similar to the finding of Rathore et al. (2010).

Sale of manure was the main source of income for the Pulikulam Cattle rearers. They earn revenue either through penning practice or collect manure, dry it and sell the manure. All the respondents $(100 \%)$ practised sale of manure. Regarding sale price of dry manure only 20 per cent of respondents were selling the manure for less than Rs. 1 per $\mathrm{kg}$ and 80 per cent respondents were selling
Table 3 Bull baiting game training followed by the Pulikulam Bull rearers $(\mathrm{n}=60)$

\begin{tabular}{llc}
\hline S. No & Characteristic/ Category & Per cent \\
\hline 1 & Swimming & \\
& One time per week & 36.66 \\
& Two times per week & 63.34 \\
2 & Soil digging using horns & \\
& Twice per week & 75 \\
& More than twice per week & 25 \\
3 & Long walk & 53.33 \\
& Yes & 46.67 \\
& No & \\
$4 \quad$ Age at first participation in gaming & 23.33 \\
& 2-3 years & 76.67 \\
\hline
\end{tabular}

it for Rs. 1 to 2 per $\mathrm{kg}$. All the respondents (100\%) sold male calves and do not sell female calves.

Data on bull baiting game practice followed by the bull rearers is presented in Table 3.Three months before the game season the bull rearers start to prepare their bulls for the game. Mostly jallikattu or bull baiting game is conducted during Januray and February month. Only during this period they feed concentrate feed to the bulls. Three main types of training are given to Pulikulam bulls to prepare them for bull baiting game. They include, swimming practice in local ponds, digging the soil with horns and long-distance walking. Swimming practice two times per week was adopted by 63.33 per cent respondents and 36.66 percent respondents allowed only one time swimming practice per week. Another important practice is allow the bulls to dig the soil vigorously using their horns, 75 per cent respondents allowed 2 times digging practice per week and 25 per cent respondents allowed more than two times digging practice per week. Another practice was allowing the bull for long distance walking, 53.33 per cent respondents allowed the bull for long walk once in a week and 46.66 percent respondents did not provide long walk practice to the bulls. Majority of respondents $(76.67 \%)$ allowed their bulls to participate in bull baiting for the first time at the age of three to four years and 23.33 per cent of respondents allowed their bulls to participate in the game for the first time at the age of two to three years. Results of this study were similar to the findings of Priyadharsini et al. (2019) who reported 51.7 per cent of respondents allowed their bulls to participate in the game first time in the age of 2.5 to 3.5 years.

\section{Conclusions}

Pulikulam cattle are reared by nomadic rearers following low or zero input system of management. They do not feed any concentrate feed to their animals. Migration for grazing is practised through a particular route in the breeding tract. Common pasture land and grazing area in the nearby hills are the main grazing sites. Pulikulam cattle are mainly reared for their manure 
and bull calves which are used in the jallikattu or bull baiting game which place a major role in conservation of this breed. No scientific management practices especially feeding management is in practice. Adoption of balanced feeding and supplementation with mineral mixture could improve the performance of this breed of cattle.

\section{Acknowledgement}

Authors are grateful to Tamil Nadu Veterinary and Animal Sciences University for providing necessary funding and support to carry out this study which is a part of Ph.D research work.

\section{References}

Deoras R, Nema RK, Tiwari SP, Singh M (2004) Feeding and housing management practices of dairy animals in Rajnandgaon of Chhatisgarh plain. Indian J Anim Sci 74 (3): 303-306

Divekar BS, Saiyed LH (2008) Feeding practices followed by professional cattle owners of Anand district. Indian J Field Vet 3:31-34

Dixit VB, Bharadwaj A, Sharma RK, Sethi RK (2010) Impact of technological interventions on buffalo based farming systems. Indian J Anim Sci 80: 63-66

Garg MK, Jain LS, Chaudhary JL (2005) Studies on housing, feeding and milking management practices of dairy cattle in Baran district of Rajasthan. Indian J Dairy Sci 58: 123-128

Godara V, Singh HKGN, Kumar S (2018) Buffalo feeding management practices adopted in rural areas of western Haryana. Small 73: 3650

Kumar S, Subash S, Jangir R (2017) Feeding and milking management practices adopted by indigenous cattle farmers in Thar desert of Rajasthan. J. Anim Health Prod 5: 14-18

Kumar U, Mehla RK, Chandra R, Roy B (2006) Studies on management practices followed by the traditional owners of Sahiwal cows in Punjab. Indian J Dairy Sci 59: 100-105
Manohar DS, Goswami SC, Bais B (2014) Study on feeding management practices of buffaloes in relationship with selected traits of respondents in Jaipur district of Rajasthan, India. Indian J Anim Res 48: $150-154$

Patel JH, Prajapati KB, Sheikh AS, Patel MD, Chaudhari SS (2016) Traditional feeding practices adopted by professional breeders of Kankrej cattle in Banaskantha district of Gujarat state. J Livest Sci 7: 49-53

Priyadharsini R, Gopinathan A, Karthickeyan SMK, Jagatheesan PR (2019) On-field sporting traits and behavior of indigenous cattle breeds in sporting events (jallikattu) of Tamil Nadu. Indian J Anim Sci 89: 1404-1407

Rathore RS, Singh R, Kachwaha RN, Kumar R (2010) Existing management practices followed by the cattle keepers in Churu district of Rajasthan. Indian J Anim Sci 80: 798-805

Sabapara GP, Desai PM, Kharadi VB, Saiyed LH, Ranjeet Singh R (2010) Housing and feeding management practices of dairy animals in the tribal area of South Gujarat. Indian J Anim Sci 80: 1022-1027

Sheikh AS, Parmar DV (2015) Kankrej cattle management practices followed in rearing at northern part of Gujarat. Life Sci Leafl 60:7886

Sheikh AS, Bhati DS, Sheikh W (2011) Feeding practices followed by professional Kankrej cow owners of Banaskantha district of North Gujarat. J Progress Agric 2: 67-69

Sinha RRK, Dutt T, Singh RR, Bhushan B, Singh M, Kumar S (2009) Feeding and housing management practices of dairy animals in Uttar Pradesh. Indian J Anim Sci 79: 829-833

Sivaganga district ground water brochure (2008) http://gswb.gov.in/district profile/Tamil Nadu/Sivaganga.pdf (Accessed $17^{\text {th }}$ June 2021)

Srinivasan G, Sathiamoorthy T (2020) Morphometric characteristics of Pulikulam Cattle breed in a nucleus herd. J Entomol Zool Stud 8:1893-1895

Tomar SK, Thakur SS (2002) Feed resources, feeding practices, milk production and disposal pattern in Karnal district. Indian J Dairy Sci 55: 306-309 